\title{
Anatomical Variations of the Caudomedial Antebrachial Muscles in the Crab-Eating Fox (Cerdocyon thous)
}

\author{
Variaciones Anatómicas de los Músculos Caudo-Mediales \\ del Antebrazo del Zorro Perruno (Cerdocyon thous)
}

\author{
Juan Fernando Vélez-García ${ }^{1}$; Catalina Patiño-Holguín ${ }^{2}$ \& Jorge Eduardo Duque-Parra ${ }^{3}$
}

VÉLEZ-GARCÍA, J. F.; PATIÑO-HOLGUÍN, C. \& DUQUE-PARRA, J. E. Anatomical variations of the caudomedial antebrachial muscles in the crab-eating fox (Cerdocyon thous). Int. J. Morphol., 36(4):1193-1196, 2018.

SUMMARY: The crab-eating fox (Cerdocyon thous) is a wild canid distributed in South America, which is susceptible to traumas caused by captors, accidents on roads, and traps. Due to these events their thoracic limbs can be involved at the level of the forearm, therefore, knowledge of the gross anatomy of its muscles is important in order to develop clinical and surgical procedures at this level compared with the domestic dog. The main objective of this investigation was report the intra and interspecific anatomical variations of the caudomedial forearm muscles in Cerdocyon thous in comparison mainly with the domestic dog. Six dead specimens from wildlife care centres of CORPOCALDAS were used. These were fixed with a solution of formaldehyde, mineral oil and phenic acid. Both thoracic limbs of each specimen were dissected from superficial to deep, emphasizing the caudomedial part of the forearm in order to review the anatomical characteristics of each muscle. These muscles were similar to those reported in the domestic dog, but some variations were observed such as the innervation of the pronator teres muscle by the musculocutaneous nerve in a specimen unilaterally; the formation of an accessory muscle from the ulnar head of the flexor carpi ulnaris muscle in most specimens; and the vestigial presence of the anconeus epitrochlearis muscle in a specimen bilaterally.

KEY WORDS: Carnivore; Canid; Forearm; Innervation; Myology.

\section{INTRODUCTION}

The crab-eating fox (Cerdocyon thous) is a wild canid widely distributed in South America. Due to its great capacity for climate adaptation and opportunism, it inhabits a wide variety of environments, including lands used for agriculture, even near human dwellings and roads, which makes it susceptible to traumas in their thoracic limbs caused by vehicles, illegal captors (Berta, 1982; Casella et al., 2006; Lucherini, 2015) and traps (Pessutti et al., 2001). Therefore, the contribution in the knowledge of musculoskeletal system will provide bases for clinical and surgical procedures that should be performed in this species.

C. thous has morphological characteristics such as a narrow skull and a dental formula characteristic of omnivores, allowing them to feed on mainly small vertebrates (Berta) and fruits (Cazetta \& Galetti, 2009). Its limbs are short and robust, facilitating its movement in forested areas (Berta), and for this, it needs the formation of an adequate musculature in its limbs, among which have been studied the muscles of the arm (Vélez et al., 2017) and some of the forearm (Vaz et al., 2011; Echeverry et al., 2015; Junior et al., 2015; Silva et al., 2015; Vélez-García et al., 2015.). Among these, intraspecific and interspecific variations with the domestic dog have been reported (Junior et al.; Vélez et al.; Vélez-García et al.; Echeverry et al.) but differences in the caudomedial muscles of the forearm have not yet been reported. Therefore, the main objective of the present study is to report the anatomical variations that can be found in these muscles.

\section{MATERIAL AND METHOD}

Six specimens were used, five females and one male, which died in wildlife care centers of CORPOCALDAS

\footnotetext{
${ }^{1}$ Departamento de Sanidad Animal, Facultad de Medicina Veterinaria y Zootecnia, Universidad del Tolima, Ibagué, Colombia.

${ }^{2}$ Semillero de investigación en Anatomía Veterinaria. Programa de Medicina Veterinaria y Zootecnia. Universidad de Caldas. Manizales. Colombia.

${ }^{3}$ Departamento de Ciencias Básicas, Facultad de Ciencias para la Salud, Universidad de Caldas, Manizales, Colombia.
} 
(Corporación Autónoma Regional de Caldas, environmental authority of the department of Caldas in Colombia). Thanks to inter-administrative agreement No. 172-2011 between CORPOCALDAS and the Universidad de Caldas, the specimens were donated and transported to the morphology veterinary laboratory of the Universidad de Caldas. There they were fixed with a solution of $10 \%$ formaldehyde, $5 \%$ mineral oil and $1 \%$ phenic acid, by application in the common carotid artery, reinforcing with subcutaneous and intramuscular infiltrations, and later disposed by immersion in the same solution without mineral oil for a week. Afterwards, their thoracic limbs were dissected from superficial to deep, emphasizing the caudomedial part of the antebrachial region to check the shape, origin, insertion and innervation of each muscle. Photographs were taken during the dissection and an anatomic description was made according to the terminology of the Nomina Anatomica Veterinaria (International Committee on Veterinary Gross Anatomical Nomenclature, 2017).

\section{RESULTS AND DISCUSSION}

The caudomedial antebrachial muscles in the crabeating fox were the following: $\mathrm{m}$. pronator teres, $\mathrm{m}$. flexor carpi radialis, $\mathrm{m}$. flexor digitorum superficialis, $\mathrm{m}$. flexor digitorum profundus, $\mathrm{m}$. pronator cuadratum, and $\mathrm{m}$. flexor carpi ulnaris. These presented anatomical characteristics (shape, origin, insertion and innervation) similar to those reported in the domestic dog (Clair, 1982; Barone, 2000; Budras et al., 2007; Hermanson, 2013; Evans \& de Lahunta, 2017) and in the same species (Vaz et al.; Silva et al.), but the following intra and interspecific anatomical variations were found:

1) In seven forearms from the laterodistal part of the ulnar head of the flexor carpi ulnaris muscle the formation of an accessory fusiform belly separated by an intermuscular septum of the main belly was observed. In the distal part of the proximal third of the forearm, the accessory belly
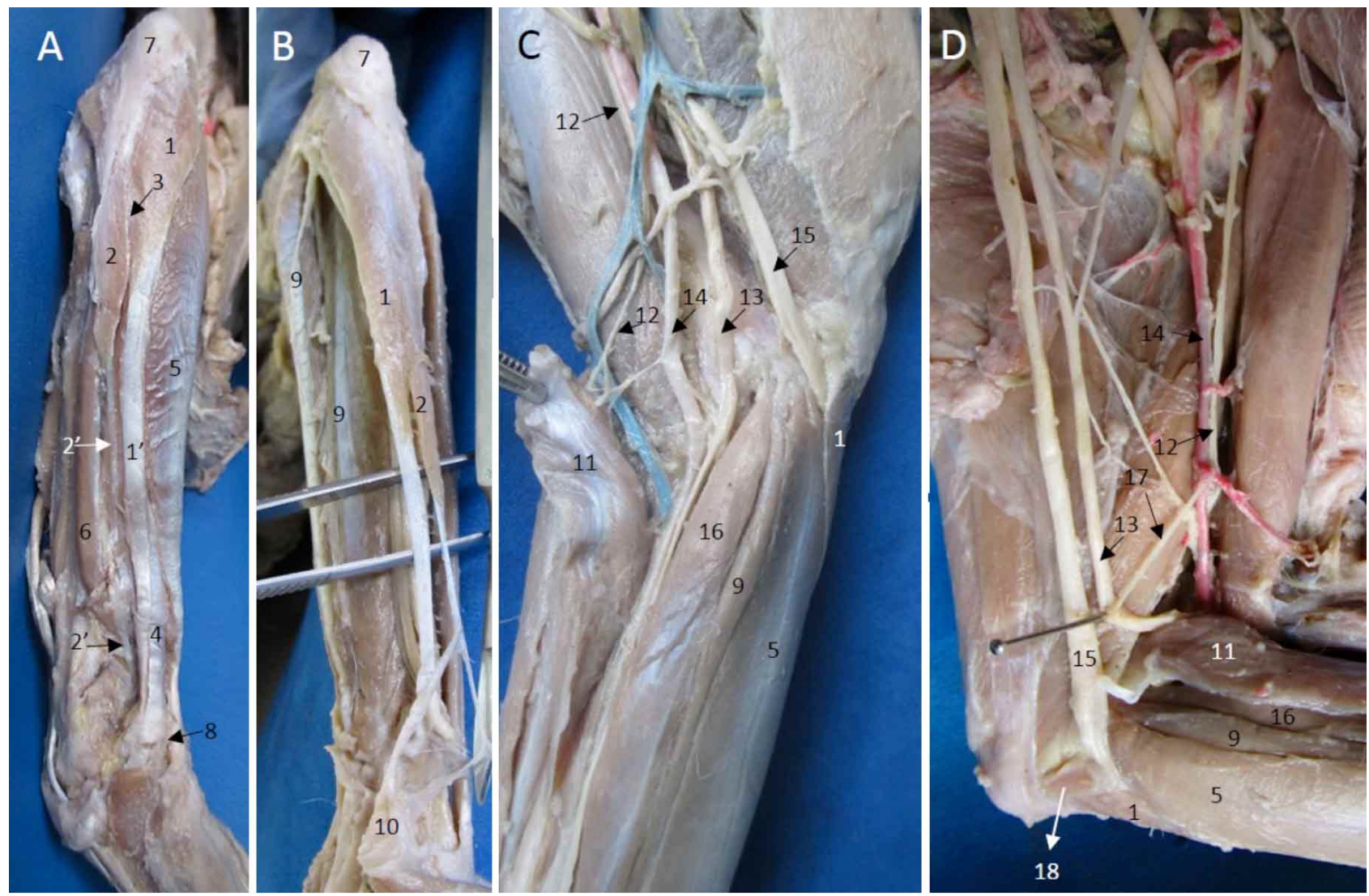

Fig. 1. A. Caudal view of the left forearm. B. Caudal view of the right forearm. C. Medial view of the right cubital region. D. Medial view of the left brachial and cubital regions. Main belly of the ulnar head of the m. flexor carpi ulnaris (1); accessory belly of 1 (2); respective tendons of 1 and $2\left(1^{\prime}, 2^{\prime}\right)$; 3) Intermuscular septum between the two bellies of the ulnar head of the m. flexor carpi ulnaris; 4) humeral head of the $\mathrm{m}$. flexor carpi ulnaris; 5) m. flexor digitorum superficialis; 6) ulnar head of the m. flexor digitorum profundus; 7) olecranon; 8) accessory carpal bone; 9) humeral head of the m. flexor digitorum profundus; 10) flexor retinaculum; 11) m. pronator teres; 12) musculocutaneus nerve; 13) median nerve; 14) brachial artery; 15) ulnar nerve; 16) m. flexor carpi radialis; 17) communicating branch of the musculocutaneus nerve to the median nerve; 18) $\mathrm{m}$. anconeus epitrochlearis. 
developed a tendon that runs parallel to the main belly tendon emitting small fascicles into it, but goes independently to deepen medially in the distal fifth of the forearm at the level of the carpal canal, where it fuses to the deep part of the flexor retinaculum (Fig. 1A), which sends a fascicle that attaches to the tendon of the flexor digitorum superficialis muscle. In the right forearm of one specimen, there was no intermuscular septum but the formation of the accessory belly and an independent tendon was observed (Fig. 1B). The muscular branch of the ulnar nerve for the ulnar head of flexor carpi ulnaris muscle crossed the intermuscular septum and supplied the accessory belly.

In Potos flavus the formation of a muscle has been reported from flexor carpi ulnaris muscle, which is named "Palmaris longus internus", but this originates from the fascia that covers the flexor carpi ulnaris muscle near the medial epicondyle of the humerus and inserts into the flexor retinaculum, and is innervated by the ulnar nerve (BeswickPerrin, 1871; Julitz, 1909), differentiating in its position and origin to the accessory belly developed from the ulnar head of the flexor carpi ulnaris muscle in $C$. thous.

2) The pronator teres muscle in the forearm of one specimen was only found innervated by the musculocutaneous nerve, even in this forearm there was no communicating branch to median nerve (Fig. 1C). In the other forearm and in the other specimens, the innervation was by the median nerve, just distal to the formation of the communicating branch of the musculocutaneus nerve to latter (Fig. 1D), being similar to the domestic dog (Barone; Budras et al; Hermanson; Evans $\&$ de Lahunta, 2017). The unique innervation of the musculocutaneous nerve to pronator teres muscle in $C$. thous corroborates that this nerve sends efferent axons in the communication with the median nerve as described in the domestic dog (Evans \& de Lahunta, 2013).

3) In two forearms of a specimen, a small vestigial muscle was observed in the proximal part to the ulnar head of the flexor carpi ulnaris muscle, located between the olecranon and the medial epicondyle of the humerus, covering the ulnar nerve (Fig. 1D), where the latter sends a branch to innervate it. This muscle has not been reported in the domestic dog (Barone; Budras et al; Hermanson; Evans \& de Lahunta, 2017), but in the domestic cat there is a well developed and constant muscle in the brachial musculature named with different terms among them the anconeus epitrochlearis muscle (Done et al., 2010) and medial anconeus muscle, which is innervated by the ulnar nerve (Barone), although none of these terms are found in the Nomina Anatomica Veterinaria (ICVGAN, 2017). However, this muscle was present in a vestigial shape in the forearm in a $C$. thous different to the cat, where it is in the arm.

\section{CONCLUSION}

The caudomedial antebrachial muscles in $C$. thous have an anatomical disposition similar to the domestic dog, but inter and intraspecific variations can be observed due to the formation of accessory muscles such as the accessory belly of the ulnar head of the flexor carpi ulnaris muscle; the vestigial presence of the anconeus epitrochlearis muscle; and the independent innervation of the musculocutaneous nerve to pronator teres muscle.

VÉLEZ-GARCÍA, J. F.; PATIÑO-HOLGUÍN, C. \& DUQUEPARRA, J. E. Variaciones anatómicas de los músculos caudomediales del antebrazo del zorro perruno (Cerdocyon thous). Int. J. Morphol., 36(4):1193-1196, 2018.

RESUMEN: El zorro perruno (Cerdocyon thous) es un cánido silvestre distribuido en Sudamérica, el cual es susceptible a traumas causados por captores, accidentes en carreteras y trampas, donde pueden verse involucrados sus miembros torácicos a nivel del antebrazo, por lo tanto, conocer la anatomía de sus músculos es importante, ya que ésta servirá como base en la realización de procedimientos clínicos y quirúrgicos a este nivel en comparación con el perro doméstico. El objetivo principal de esta investigación fue reportar las variaciones anatómicas intra e interespecíficas de los músculos caudo-mediales del antebrazo de $C$. thous en comparación principalmente con el perro doméstico. Se utilizaron seis especímenes muertos bajo la jurisdicción de CORPOCALDAS. Estos se fijaron con una solución en mezcla de formaldehído, aceite mineral y ácido fénico. Se diseccionaron de superficial a profundo los dos miembros torácicos de cada espécimen, haciendo énfasis en la parte caudo-medial del antebrazo para revisar las características anatómicas de cada músculo, las cuales fueron similares a las reportadas al perro doméstico, pero se observó en un espécimen de manera unilateral la inervación al músculo pronador teres por parte del nervio musculocutáneo; en la mayoría de especímenes se observó la formación de un músculo accesorio a partir de la cabeza ulnar del músculo flexor ulnar del carpo; y en un espécimen la presencia vestigial del músculo ancóneoepitroclear.

PALABRAS CLAVE: Antebrazo; Cánido; Carnívoro; Inervación; Miología.

\section{REFERENCES}

Barone, R. Anatomie Comprée des Mammifères Domestiques. Tome 2. Arthrologie et Myologie. Paris, Vigot, 2000.

Berta, A. Cerdocyon thous. Mamm. Species, (186):1-4, 1982.

Beswick-Perrin, J. On the myology of the limbs of the kinkajou (Cercoleptes caudivolvulus). Proc. Zool. Soc. Lond., 1871:547-559, 1871.

Budras, K. D.; McCarthy P. H.; Fricke, W. \& Richter, R. Anatomy of the Dog. $5^{\text {th }}$ ed. London, Manson Pub., 2007. 
Casella, J.; Cáceres, N.; Goulart, C. \& Filho, A. Uso de Sensoriamento Remoto e Análise Espacial na Interpretação de Atropelamentos de Fauna entre Campo Grande e Aquidauana. Campo Grande, MS Anais $1^{\circ}$ Simp. de Geotec. Pant., 2006. pp.321-6.

Cazetta, E. \& Galetti, M. The Crab-eating Fox (Cerdocyon thous) as a secondary seed disperser of Eugenia umbelliflora (Myrtaceae) in a Restinga forest of southeastern Brazil. Biota Neotrop., 9(2):271-4, 2009.

Done, S. H.; Goody, P. C.; Evans, S. A. \& Stickland, N. C. Color Atlas of Veterinary Anatomy. Vol. 3. The Dog and Cat. Barcelona, Elsevier, 2010.

Echeverry, J. S.; Vélez, J. F. \& Sánchez, C.A. Descripción anatómica de los músculos cráneo-laterales superficiales del antebrazo del zorro perruno (Cerdocyon thous). Rev. Colomb. Cienc. Anim., 8(1):44-51, 2015.

Evans, H. \& de Lahunta, A. Spinal Nerves. En: Evans, H. E. \& de Lahunta, A. Miller'S Anatomy of the Dog. $4^{\text {th }}$ ed. St. Louis, Elsevier, 2013. pp.621-

Evans, H. E. \& de Lahunta, A. Guide to Dissection of the Dog. 8th ed. St. Louis, Missouri, Elsevier, 2017.

Hermanson, J. W. The Muscular System. En: Evans, H. E. \& de Lahunta, A. Miller's Anatomy of the Dog. 4 $^{\text {th }}$ ed. St. Louis, Elsevier, 2013.

International Committee on Veterinary Gross Anatomical Nomenclature (ICVGAN). Nomina Anatomica Veterinaria. $6^{\text {th }}$ ed. Knoxville, Editorial Committee Hannover, 2017.

Julitz, C. Osteologie und Myologie der Extremitäten und des Wickelschwanzes vom Wickelbären, Cercoleptes caudivolvulus, mit besonderer Berücksichtigung der Anpassungserscheinungen an das Baumleben. Arch. Naturgesch., 75(1):143-88, 1909.

Junior, P. D. S.; dos Santos, L. M.; Nogueira, D. M.; Abidu-Figueiredo, M. \& Santos, A. L. Occurrence and morphometrics of the brachioradialis muscle in wild carnivorans (Carnivora: Caniformia, Feliformia). Zoologia (Curitiba), 32(1):23-32, 2015.

Lucherini, M. Cerdocyon thous. The IUCN Red List of Threatened Species 2015:e.T4248A81266293, 2015. Available from: http://dx.doi.org/ 10.2305/IUCN.UK.2015-4.RLTS.T4248A81266293.en.

Pessutti, C.; Santiago, M. E. B. \& Oliveira, L. T. F. Order Carnivora, Family Canidae (Dogs, foxes, Maned foxes). In: Fowler, M. E. \& Cubas, Z. S. (Eds.). Biology, Medicine, and Surgery of South American Wild Animals. Ames, Iowa State University Press, 2001. pp.286.

Silva, M. F. M.; Souza, W. V.; Almada, R. M. F.; Carvalho, A. D. \& SouzaJúnior, P. Anatomía comparada de los músculos supinador y pronador redondo de tres especies carnívoras silvestres. Rev. Argent. Anat. Online, 6(3):117-22, 2015.

Vaz, M. G. R.; de Lima, A. R.; de Souza, A. C. B.; Pereira, L. C. \& Branco, É. Estudo morfológico dos músculos do antebraço de cachorro-do-matode-orelhas-curtas (Atelocynus microtis) e cachorro-do-mato (Cerdocyon thous). Biotemas, 24(4):121-7, 2011.

\author{
Corresponding author: \\ Juan Fernando Vélez García \\ Altos de Santa Helena \\ Departamento de Sanidad Animal \\ Facultad de Medicina Veterinaria y Zootecnia \\ Universidad del Tolima \\ lbagué \\ COLOMBIA
}

Email: jfvelezg@ut.edu.co

Received: 14-02-2018

Accepted: 09-06-2018 